\title{
Description of a new species of Tetranematichthys (Siluriformes: Auchenipteridae) from the lower Amazon basin, Brazil
}

\author{
Luiz Antônio Wanderley Peixoto and Wolmar Benjamin Wosiacki
}

Tetranematichthys barthemi is described from the mouth of the rio Trombetas and related tributaries (rios Saracá and Araticum) and rio Urubu, tributary of the rio Amazon. Tetranematichthys barthemi shares with its congeners the anterior alignment of the mandibular barbels and well-developed portion of the protractor hyoid muscle connected to the mandibular barbel. It is distinguished from these species by a serrated anterior margin on the distal portion of the mandibular barbel, different from the more derived state which is composed of conspicuous digitiform elaboration in the distal portion of the barbel. Tetranematichthys barthemi can also be distinguished from its congeners by combination of characters related to morphometry and coloration pattern. Comments on sexual dimorphism, changes to the extremities of the mandibular barbels and possible interspecific relationships are presented herein.

Tetranematichthys barthemi é descrita para a foz do rio Trombetas e tributários correspondentes (rios Saracá e Araticum), e rio Urubu, tributário do rio Amazonas. Tetranematichthys barthemi compartilha com seus congêneres (T. wallacei e T. quadrifilis) o alinhamento anterior dos barbilhões mandibulares e a porção do músculo protrator hióide ligado ao mesmo barbilhão bem desenvolvida. Distingue-se destas espécies por apresentar a porção distal do barbilhão mandibular serreada na margem anterior, diferente do estado, mais derivado, observado em seus congêneres, com conspícuas digitalizações na porção distal. Distingue-se, também, de cada uma das espécies por conjuntos de caracteres combinados relacionados à morfometria e padrão de coloração. Comentários sobre dimorfismo sexual, modificações das extremidades do barbilhão mandibular e de relacionamento interespecíficos são apresentados.

Key words: Neotropical, Systematics, Catfishes, Auchenipterinae, Lower Amazon.

\section{Introduction}

Auchenipteridae is a natural group (de Pinna, 1998), with 20 genera and more than 90 nominal species distributed from Panama to Argentina (Ferraris, 2007). An important feature of the group is a modification of the first anal fin rays of the male, forming an ejaculatory duct with a urogenital opening in the distal portion, making it possible for internal fertilization to occur (Burgess, 1989; de Pinna, 1998; Ferraris, 2003). The family has two subfamilies, Centromochlinae with four genera and Auchenipterinae with 16 genera, including Tetranematichthys.

Tetranematichthys is a monophyletic group composed of two species, T. quadrifilis and T. wallace $i$ that shares three synapomorphies presented in Vari \& Ferraris (2006). The genus was originally described by Bleeker (1858) to allocate Ageneiosus quadrifilis. It remained as a monospecific genus for 148 years, until Vari \& Ferraris (2006) described T. wallacei, with wide distribution throughout the Amazon Basin and estimated for T. quadrifilis a distribution restricted to the rio
Guaporé, a tributary of the upper rio Madeira.

Based on analysis of material collected in rios Saracá and Araticum, tributaries of the lower rio Trombetas, and a specimen provided from the rio Urubu, tributary of the rio Amazon, we identified a new species of Tetranematichthys, which is described herein.

\section{Material and Methods}

Morphometric data follow Vari \& Ferraris (2006), except for the length of the mandibular barbel which is measured from its insertion until its distal portion. Measurements were obtained with $0.1 \mathrm{~mm}$ precision Mitutoyo calipers. Meristic data were obtained with the aid of a stereomicroscope and radiographs. Radiographs were obtained with an Orion 100 apparatus, depth 100 and time 0.2 in samples of 154.2-175.7 $\mathrm{mm} \mathrm{SL}$, and time 0.1 for samples of $123.3 \mathrm{~mm} \mathrm{SL}$. Gill rakers were counted from the first gill arch on the left side of each specimen. Institutional abbreviations follow Reis et al. (2003). Morphometric abbreviations are SL, standard length, HL, head

Museu Paraense Emílio Goeldi, Setor de Ictiologia. Av. Magalhães Barata, 376, CP 399, 66040-170 Belém, PA, Brazil. luizwp@yahoo.com.br, wolmar@museu-goeldi.br 
length, and $\mathrm{HO}$, head width at posterior margin of the orbit. Meristic data for the holotype are marked with an asterisk (*).

\section{Results}

\section{Tetranematichthys barthemi new species Figs. 1-2}

Holotype. MPEG 11081, $154.2 \mathrm{~mm}$ SL, sexually mature male, Brazil, Pará, Oriximiná, rio Araticum, rio Trombetas basin, $1^{\circ} 45^{\prime} 34.7$ 'S $56^{\circ} 22^{\prime} 35.5^{\prime \prime}$, 22 Oct 2007, W. B. Wosiacki, L. A. W. Peixoto \& T. O. B. Ruffeil.

Paratypes. Brazil, Pará: MPEG 11013, 2, 158.2-164.4 mm SL, collected with the holotype. MPEG 14565, 1, $175.7 \mathrm{~mm}$ SL, Pará, Oriximiná, rio Saracá, rio Trombetas basin, $1^{\circ} 48^{\prime} 39.2$ "S $56^{\circ} 16^{\prime} 20^{\prime}$ W, 18 Oct 2007, W. B. Wosiacki, L. A. W. Peixoto \& T. O. B. Ruffeil. Amazonas: INPA 14163, 1, 123.3 mm SL, Manaus, igarapé Gavião, rio Urubu, rio Negro basin, Esteio Farm, Reserve 1401, 2³0'S 6059’W, 29 Oct 1996, C. Bührnheim.

Diagnosis. Tetranematichthys barthemi is distinguished from T. wallacei and T. quadrifilis by a serrated margin on the distal portion of the mandibular barbel (Fig. 3) (vs. presence of conspicuous digitiform elaboration); by the length of the mandibular barbel, $4.5-6.0 \% \mathrm{HL}$ (vs. 6.3-23.5\% in T. quadrifilis and $7.4-24.6 \%$ in $T$. wallacei); by a pale ventral region with sparse chromatophores (vs. uniformly brown with darkened spots); by a large pale stripe, more evident in females, immediately above the lateral line, extending from the humeral region to the transverse line above the end of the adipose fin (vs. narrow pale stripe in both sexes or absent); by the presence of irregular patches, which can form a pale distinct stripe in the medial portion of the pelvic fin ( $v s$. uniform dark pigmentation ); by the absence of darkened spots on the anal fin in females ( $v s$. presence in both sexes); by the absence of irregular dark patches along the body ( $v s$. patches present); by the two pale distinct vertical stripes on the caudal fin in specimens over $160 \mathrm{~mm} \mathrm{SL}$ ( $v s$. only irregular patches or vertical stripe followed by irregular patches). It can be further distinguished from $T$. wallacei by the small size of the snout, 28.8-34.5\% HL ( $v s .41 .2-49.3 \%$ ) and by the width of the body at the insertion of the pectoral fin, 82.1-88.7\% HL (vs. 69.2$79.3 \%$ ). Tetranematichthys barthemi can be further distinguished from $T$. quadrifilis by the reduced size of principal unbranched ray of the upper caudal-fin lobe, 15.6$16.9 \%$ SL (vs. 18.1-19.9\%), by the length of head, 24.4-28.2\% SL (vs. 28.5-32.3\%) and by the width of the body at the insertion of the pectoral fin, 91.6-111.3\% HO (vs. 117.0-125.0\%).

Description. Morphometric data given in Table 1. Body tall anteriorly, more slender after pectoral-fin insertion. Portion of dorsal-fin insertion taller than pre-dorsal region, more pronounced in mature males than in females and sexually immature males. In lateral view, dorsal profile of head straight or slightly concave from upper lip to transverse line that passes along posterior margin of eyes, ascending gradually in females and abruptly in mature males, until dorsal-fin origin. Dorsal profile of trunk slightly concave anteriorly, becoming slightly convex immediately anterior to adipose fin. Base of adipose fin descending from origin to beginning of dorsal profile of slightly concave caudal peduncle. Ventral profile of head straight from lower lip to point over transverse line at base of pectoral fin, sharply convex until anus, concave from anterior margin of anus to anal-fin origin. Base of anal fin slightly convex from its insertion to its end. Ventral profile of caudal peduncle straight or slightly concave and short, noticeably smaller than dorsal profile.

Head conspicuously compressed in pre-orbital portion, rounded in dorsal view. Opercular opening reduced, more apparent in lower portion, near pectoral-fin insertion. Orbits rounded, turned laterally, visible in dorsal and ventral view. Pair of maxillary barbels present. Maxillary barbels pronounced and ossified in mature males, extending until pectoral-fin insertion. Maxillary barbels with epidermal protrusions throughout, located on dorsal surface, less concentrated in anterior portion, extending beyond distal portion of barbel in mature males. Upward curve present on medial portion of maxillary barbel in mature males; females and immature males with short maxillary barbels, not ossified, without medial curve, size similar to orbital diameter. Pair of minute mandibular barbels, slightly serrated on anterior distal portion, or serrations absent; when serrations absent distal portion of barbel lanceolated. Length of mandibular barbel less than orbital diameter. Mandibular barbel aligned anteriorly in preserved specimens, towards posterior surface of jaw. Mouth terminal, opening between orbits. Pre-maxillary teeth small, pointed distally, with posterior curvature, arranged in $10 *(4)$ or 11(1) irregular rows along surface of pre-maxilla. Dentary with $8(1)$ or $9 *(4)$ irregular rows of teeth. Maxilla more prominent than dentary. Branquiostegal membrane attached to isthmus. Branchiostegal rays visible in radiographed specimens $6 *(3)$ or $8(2)$. Opercular opening prominent, reaching from anterior pectoral-fin insertion to humeral portion. First gill arch with 14(1), 15*(1) or 16(3) gill rakers.

Lateral line complete, clear zig-zag pattern anteriorly, less pronounced after half of body, bifurcated posteriorly over caudal-fin base. Alignment of pectoral-fin insertion occurring parallel to operculum in ventral view.

Dorsal-fin rays I,6, second branched ray larger than other branched rays. Dorsal-fin spine beyond pelvic-fin insertion in mature males, reaching transverse line that passes over anal-fin insertion; in females and immature males spine not reaching transverse line that passes over pelvic-fin insertion; immature males and females with dorsal spine serrated on posterior surface (19-21 serrations), anterior surface slightly rough, without serrations, mature males with 48-50 serrations on anterior surface, posterior surface without rugosities. Adipose-fin size equivalent to orbital diameter in both sexes. Anal-fin origin posterior to middle of SL, margin convex, strongly convex posteriorly, rays progressively longer from posterior half, last rays minute, membrane joining caudal 


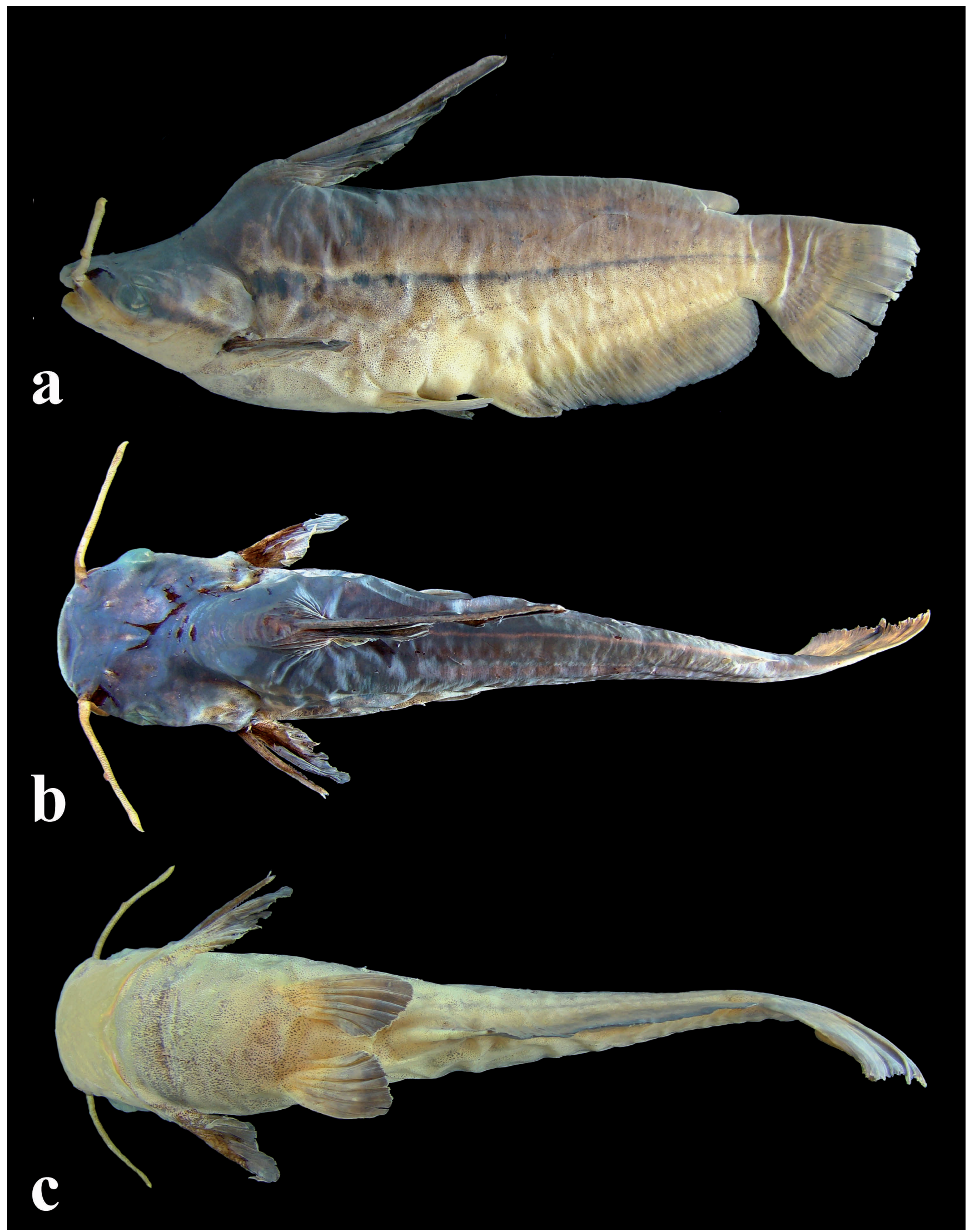

Fig. 1. Tetranematichthys barthemi, holotype, male, MPEG 11081, $154.2 \mathrm{~mm} \mathrm{SL}$. (a) lateral, (b) dorsal, and (c) ventral views. 


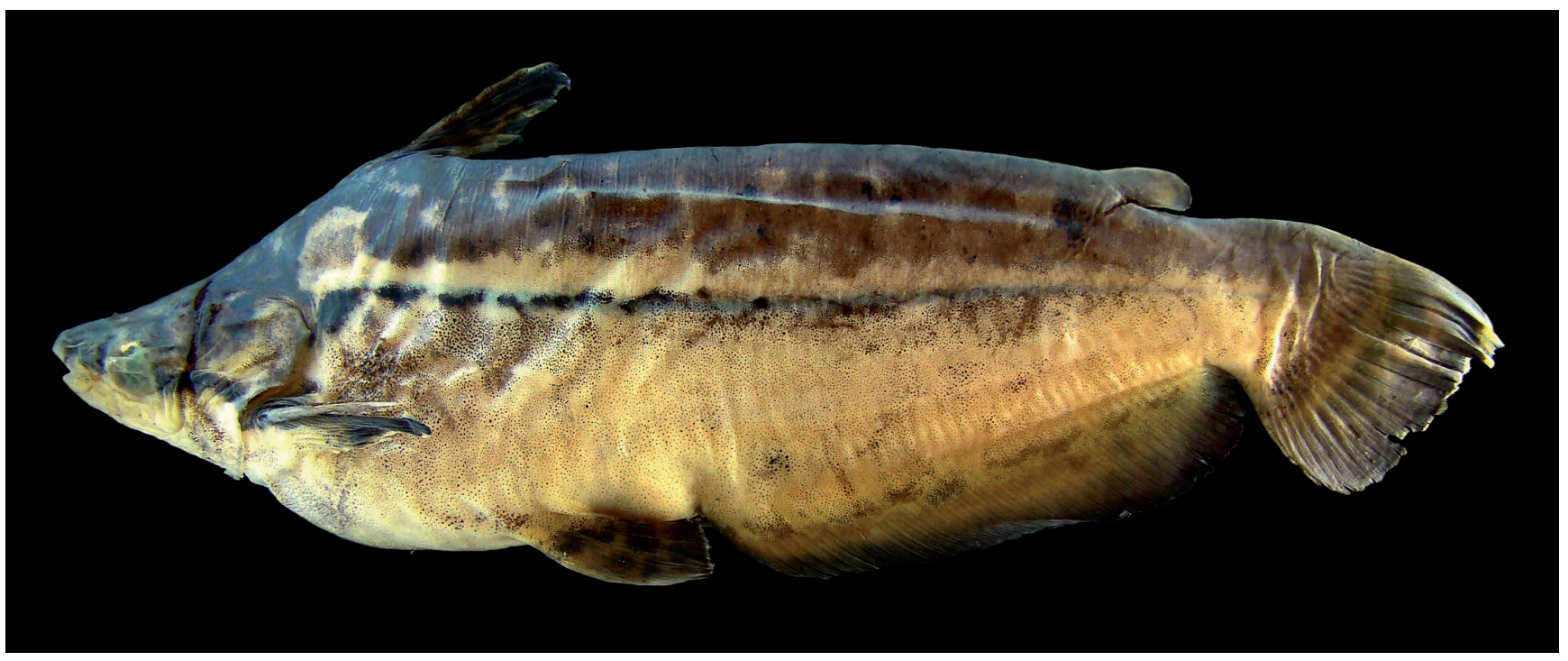

Fig. 2. Tetranematichthys barthemi, paratype, female, MPEG 14565, 175.7 mm SL. Lateral view.

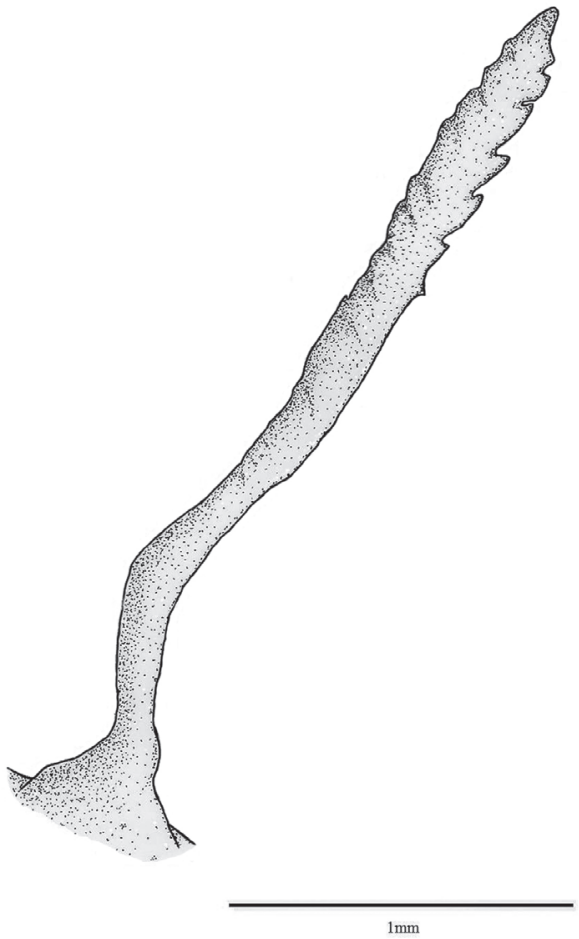

Fig. 3. Mandibular barbel of Tetranematichthys barthemi, MPEG $14565,175.7 \mathrm{~mm} \mathrm{SL}$, showing the fleshy serrated distal portion. Scale bar $=1 \mathrm{~mm}$.

peduncle or caudal fin absent. Anterior five anal-fin rays characterized by changes in distal portion, ejaculatory duct structure in sexually mature males with reproductive purpose. Anal-fin rays iii,35*(2), iii,36(2), iii,37(1). Oblique caudal fin, upper lobe longer than lower lobe. Main caudal-fin rays i,7,7,i. Pelvic-fin rays i,6, second branched ray longest, extending posteriorly from anal-fin insertion. Distal margin convex. Pectoral-fin rays I,9*(2) or I,10(3). Spine well-developed, 21(1), $22(1), 24 *(2), 26$ (1) twisted serrations in posterior margin.
Anterior surface with slight rugosities. Branched rays becoming progressively smaller, second ray longest.

Total vertebrae $39 *(1), 40(2)$ or $41(2)$. Vertebrae $7-8$ proportionally thicker. Hemal spines 13-15 larger than others. Pleural ribs 7. First anal-fin pterygiophore contacting anterior portion of $12^{\text {th }}$ hemal spine. Anal-fin pterygiophores 1-2 proportionally larger than others. Pterigiophore rays of mature males more deeply embedded in hemal spines than those of females and immature males.

Color in alcohol. Dorsal region of body with brown background and irregular lighter areas. Mid-ventral region with light coloring in specimens larger than $123 \mathrm{~mm} \mathrm{SL}$. Back

Table 1. Morphometric data of the holotype and paratypes (4 exs) of Tetranematichthys barthemi.

\begin{tabular}{|c|c|c|}
\hline & Holotype & Paratypes \\
\hline Standard length (SL) in $\mathrm{mm}$ & 154.2 & $123.3-175.7$ \\
\hline \multicolumn{3}{|l|}{ Percents of SL } \\
\hline Body depth at anal-fin origin & 28.5 & 26.7-29.7 \\
\hline Body width at pectoral-fin insertion & 21.2 & $20.8-23.4$ \\
\hline Caudal-peduncle depth & 12.8 & $11.6-12.3$ \\
\hline Snout to dorsal-fin origin & 33.0 & 28.7-31.4 \\
\hline Snout to anal-fin origin & 55.9 & $53.9-58.6$ \\
\hline Length of base of anal fin & 39.8 & $38.4-41.5$ \\
\hline Snout to pelvic-fin insertion & 44.4 & $43.8-46.5$ \\
\hline Length of first dorsal-fin ray & 31.5 & $12.0-33.2$ \\
\hline Length of first pelvic-fin ray & 13.5 & $11.7-12.9$ \\
\hline Length of pectoral-fin spine & 15.3 & $13.8-16.0$ \\
\hline Length of first pectoral-fin ray & 15.7 & $14.1-16.8$ \\
\hline Length of dorsal principal caudal-fin ray & 16.9 & $15.6-16.6$ \\
\hline Head length (HL) & 24.7 & $24.4-28.2$ \\
\hline \multicolumn{3}{|l|}{ Percents of HL } \\
\hline Snout length & 28.8 & 29.7-34.5 \\
\hline Horizontal diameter of orbit & 18.7 & $16.3-17.2$ \\
\hline Interorbital width & 71.3 & $68.8-72.6$ \\
\hline Head width at posterior margin of orbit $(\mathrm{HO})$ & 84.2 & $77.8-82.9$ \\
\hline Body width at pectoral-fin insertion & 88.5 & $82.1-88.7$ \\
\hline Mandibular barbel (mental) & 4.5 & $5.2-6.0$ \\
\hline \multicolumn{3}{|l|}{ Percents of $\mathrm{HO}$} \\
\hline Body width at pectoral-fin insertion & 102.2 & $91.6-111.3$ \\
\hline
\end{tabular}


portion of head brown with irregular light areas in upper portion of orbit. Ventral region of head light colored. Upper and lower lips brown, upper lips darker. Lower lip covered by minute chromatophores, more concentrated at edge. Maxillary barbel distinctly lighter than upper lip, with blurred blotches throughout length. Maxillary barbels of females not pigmented. Mandibular barbel not pigmented. Horizontal stripe in pre- and post-orbital region with uniform pigmentation, extending from snout to pectoral-fin insertion. Slender light stripe on sagittal line, between end of dorsal-fin base and tip of adipose-fin. Cleithral portion with small chromatophages on specimens up to $160 \mathrm{~mm}$ SL. Distinct horizontal stripe with more prominent light colored area in mature females larger than $165 \mathrm{~mm}$ SL. Ventral region of abdomen with light color pattern, usually uniform, without blurred dark patches. Presence of horizontal dark stripe extending from posterior opercular region to beginning of caudal-fin.

Irregular humeral blotch, with dark center and blurred edge. Horizontal stripe extending from dorsal portion of humeral patch. Dorsal region of horizontal patch with large light colored area in specimens between 154 and $176 \mathrm{~mm} \mathrm{SL}$. In females with 165-176 mm SL humeral portion of light colored area more prominent than in males of similar size. Dorsal surface of caudal peduncle with light colored irregular patches and ventral surface with minute dispersed chromatophores. Less intense color pattern than in dorsal region of caudal peduncle. Dorsal fin with uniform pigmentation in males larger than 150 $\mathrm{mm}$ SL, including spine and branched rays; in females, dorsal spine with uniform pigmentation, surface of branched rays with irregular light colored areas; margin of dorsal-fin not pigmented in both sexes. Adipose-fin with brown pigmentation and light colored margin. Caudal-fin light brown; two distinct light colored stripes; second vertical stripe in specimens smaller than $155 \mathrm{~mm}$ SL may form irregular patches; margin not pigmented. Anal-fin light colored with dark rounded patches in males greater than $154 \mathrm{~mm} \mathrm{SL}$, absence of dark patches in females of 120 to $176 \mathrm{~mm} \mathrm{SL}$; dark brown color on margin, becoming less intense on upper part in both sexes. Pelvic-fin brown with light colored areas, forming distinct light colored stripe (in four specimens.); margin not pigmented. Pectoral-fin spine strongly pigmented; branched rays brown, with similar pattern on ventral portion, in specimens larger than $155 \mathrm{~mm}$ SL in both sexes. Margin not pigmented.

Distribution. Tetranematichthys barthemi is recorded from the lower Amazon, between the mouth of the rio Negro and the mouth of the rio Trombetas (Fig. 4).

Sexual dimorphism. Presence of sexual dimorphism characterized by the increase in size of the dorsal-fin spine in males, which can reach slightly more than double the size of the dorsal spine in females. First dorsal-fin ray of males with minute serrations on anterior surface and, in females, protrusions on posterior region. Dorsum more prominent and noticeably taller in males. Maxillary barbels more pronounced in males, regularly reaching pectoral-fin insertion, and females with smaller maxillary barbels, extending until anterior margin of orbit. Anal-fin rays 1-5 in males modified to form copulatory organ in the distal portion.

Coloration pattern without dark irregular patches on analfin base of females, different from males in which patches are present. Presence of more obvious light colored area in humeral portion of the body in females, differing from the males, in which this area is less prominent or absent.

Etymology. The specific epithet barthemi is a tribute to Ronaldo Borges Barthem, researcher of the MPEG, for his contribution to the field of ichthyology, in particular to fisheries ecology in the Amazon.

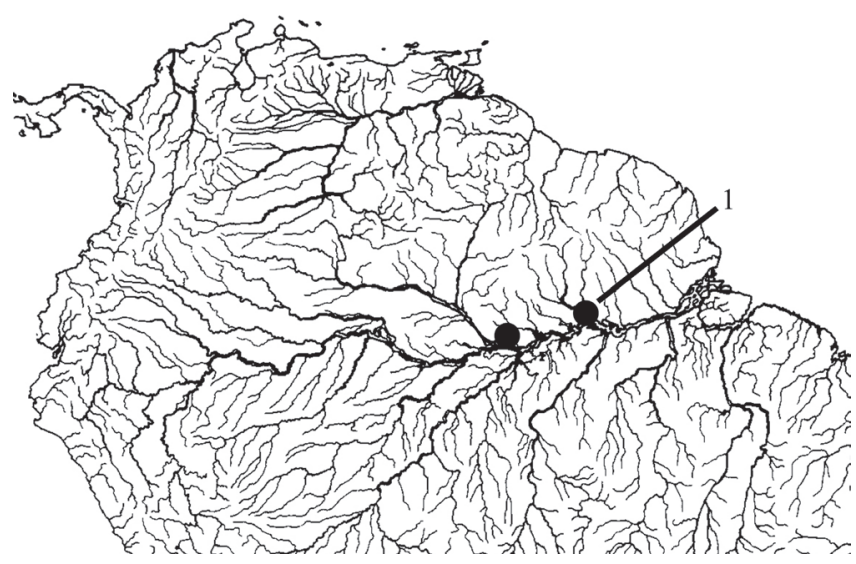

Fig. 4. Distribution of Tetranematichthys barthemi. $1=$ type locality. Point 1 represents more than one locality.

\section{Discussion}

Vari \& Ferraris (2006) proposed three synapomorphies for Tetranematichthys including (1) anterior alignment of the mandibular barbels, and (2) pronounced development of hyoid protactor attached to anterior surface of mandibular barbels, both present in T. barthemi. The inclusion of T. barthemi in the genus Tetranematichthys is also diagnosed by the presence of a single pair of mandibular barbels, a distinctive character among the Auchenipterinae, in which most included species have two distinct pairs. An exception is Ageneiosus, in which these barbels are absent. As discussed by Vari and Ferraris (2006) the presence of only one pair of mandibular barbels is recorded for Gelanoglanis (Centromochlinae). In T. barthemi, as in the other species of the genus, the mandibular barbels are reduced in size and do not reach the posterior margin of the opercular membrane ( $v s$. extend well beyond this point in Gelanoglanis). Tetranematichthys barthemi can be distinguished from the species of Gelanoglanis by its general body and head shape. Tetranematichthys is a member of the clade Auchenipterinae, sharing synapomorphies within this group (de Pinna, 1998), whereas Gelanoglanis belong to another monophyletic unit 
within the family Auchenipteridae: the Centromochlinae (Ferraris, 1988; Soares-Porto et al., 1999).

The third synapomorphy proposed by Vari \& Ferraris (2006), (3) the presence of multiple fleshy digit-like projections in the distal portion of the mandibular barbel, is quite different in T. barthemi with either a lanceolated extremity or by being slightly serrated on anterior margin (Fig. 3), without the digitiform elaboration present in T. wallacei and T. quadrifilis. In Ageneiosus, sister group of Tetranematichthys (de Pinna, 1998), the absence of the mandibular barbel is a synapomorphy for the genus. In the other genera the mandibular barbel is slender, without expansions or projections and probably represents a basal state. The changes observed in Tetranemathichthys, serrated extremities observed in $T$. barthemi, and digit-like projections in T. wallacei and $T$. quadrifilis, are probably derived sequential states. As a result, possible relationships between these species, based on the shape of the mandibular barbel extremities, places T. barthemi as a sister species of $T$. wallacei plus T. quadrifilis. However, the analysis of more characters in a phylogenetic framework should be undertaken to better understand the relationships between the species of Tetranematichthys.

The specimens of Tetranematichthys wallacei and $T$. quadrifilis examined showed varying lengths of mandibular barbels in proportion to HL (6.3-23.5\% in T. quadrifilis and $7.4-24.6 \%$ in $T$. wallacei). In individuals of T. barthemi the mandibular barbel is proportionally smaller than in the other two species (4.5-6.0\% of HL). The small size of the mentonian barbels in $T$. barthemi could be due to predation or a simple accident, among other possibilities. However, in the type material of $T$. barthemi we did not observe any damage or cuts, suggesting that the barbels are intact in the specimens. The morphology of this barbel in T. barthemi consists of a cylindrical structure with a slightly serrated or lanceolate anterior margin (Fig. 3). During the collection of the type material of $T$. barthemi, in rio Araticum, four specimens of $T$. wallacei were also collected, three of which have the conspicuous finger-like projections on the distal portion of the mentonian barbels. In only one specimen of $T$. wallacei (MPEG 17450) the projections are missing in both barbels, which have clearly been damaged since there are faults and alterations in the morphology of the normal structure. The mentonian barbels of the specimens of T. quadrifilis analyzed had finger-like projections on their distal portion, however, these were damaged in some specimens and in some cases these projections were probably lost as there were only visible traces of them. The morphology and the size of the barbels of $T$. barthemi and their congeners, suggests that there are no differences with regard to genus or to standard length.

Vari \& Ferraris (2006) distinguished Tetranematichthys wallacei from T. quadrifilis, based on the different width of the body at the pectoral-fin insertion with regard to head width measured at the posterior margin of the ocular orbit (0.99-1.10 vs. 1.17-1.25, respectively). However, Vari \& Ferraris (2006; tab. 1) presented the width of the body at the pectoralfin insertion and head width at posterior margin of ocular orbit as proportions of head length, repeating body width at pectoral-fin insertion as a proportion of standard length. There is probably a typing error in T. quadrifilis which records a variation of $0.24-20.27$. The recorded measurements by Vari and Ferraris (2006) for T. wallacei were 0.20-0.25. In $T$. barthemi the width of the body at the pectoral-fin insertion as a proportion of standard length is 20.8-23.4. At any rate, $T$. barthemi presented different proportions from T. quadrifilis with regard to the width of the body at the pectoral-fin insertion as a proportion of head width at the posterior margin of the ocular orbit, 91.6-111.3 (vs.117.0-125.0).

Vari \& Ferraris (2006) obtained for T. quadrifilis, variation in the length of the head 30 to $33 \%$ SL, slightly different from the material obtained in this comparative study (28.5-32.3\% $\mathrm{SL})$. At any rate, $T$. barthemi is distinct from $T$. quadrifilis by having distinct head length measurements (24.4-28.2\% SL).

\section{Key to the species of Tetranematichthys}

1. Lateral margin of head at anterior portion of orbit, parallel to the posterior limit of operculum, in ventral view (Fig. $5 \mathrm{a}$ ); ventral region light or dark colored; presence or absence of digit-like projections on distal portion of mandibular barbel; length of mandibular barbel 5.2-24.6\% $\mathrm{HL}$; length of main ray of upper caudal-fin lobe $14.5-20.5 \%$ SL; body width at pectoral-fin insertion 82.1- 110.0\% HO; head length $24.4-31.0 \%$ SL ................................................. 2

1a. Lateral margin of head at anterior portion of orbit, diverging laterally to posterior limit of operculum, in ventral view (Fig. 5b); uniform color pattern with dark patches along the body; presence of digit-like projections on distal portion of mandibular barbel; length of mandibular barbel 6.3-23.5\% HL; length of main ray of upper caudal-fin lobe 18.1-19.9\% SL; body width at pectoral-fin insertion 117.0$125.0 \% \mathrm{HO}$; head length $28.5-32.3 \% \mathrm{SL}$....... T. quadrifilis (rio Guaporé Basin)

2. Dorsal region without blurred light area; dark patches of pigmentation present along the body; ventral region dark colored; one light colored stripe present on the caudal-fin; pelvic-fin without distinct light colored stripe; anterior margin of mandibular barbel with digit-like projections; length of mandibular barbel 7.4-24.6\% HL; snout length 41.2-49.3\% HL; body width at pectoral-fin insertion 69.2$79.3 \%$ HL ......... T. wallacei (rio Tocantins, rio Orinoco and several stretches of the rio Amazon, except rio Guaporé)

2a. Dorsal region with blurred light area; dark patches of pigmentation absent along the body; ventral region light colored; two light colored stripes present on the caudalfin; pelvic-fin with distinct light colored stripe; anterior margin of mandibular barbel serrated on distal portion; length of mandibular barbel 4.5-6.0\% HL; snout length 28.8$34.5 \% \mathrm{HL}$; body width at pectoral-fin insertion $82.1-88.7 \%$ HL....... T. barthemi (rio Saracá, rio Araticum and rio Urubu).

Comparative examined material. Brazil. Tetranematichthys wallacei: MPEG $8762,1,113.4 \mathrm{~mm} \mathrm{SL}$, rio Caxiuanã, $1^{\circ} 45^{\prime} \mathrm{S}$ 51³9’W; MPEG 6528,1, $125.88 \mathrm{~mm}$ SL, rio Amazonas, $1^{\circ} 42^{\prime} \mathrm{S}$ 


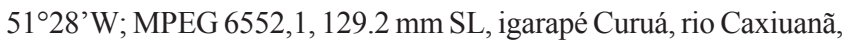
143'S 51²7'W; MPEG 6501,1, 126.9 mm SL, rio Amazonas, igarapé Puraquequara, $1^{\circ} 42^{\prime} \mathrm{S} 51^{\circ} 28^{\prime} \mathrm{W}$; MPEG 8654,1, $125.4 \mathrm{~mm}$ SL, rio Pracupi, tributary of rio Amazonas, $2^{\circ} 09^{\prime} \mathrm{S} 51^{\circ} 31^{\prime} \mathrm{W}$; MPEG $8656,1,143.1 \mathrm{~mm}$ SL, rio Caxiuanã, $1^{\circ} 46^{\prime}$ 'S 51³61W; MPEG $3268,1,123.1 \mathrm{~mm}$ SL, rio Marauiá, tributary of rio Negro; MPEG 17450,4, 111.3-164.4 mm SL, rio Araticum, tributary of rio Trombetas; MPEG 15832,1, 103.75 mm SL, rio Amazonas; MPEG 16199,1, 134.36 mm SL, igarapé Curuá, rio Caxiuanã, $1^{\circ} 45^{\prime} \mathrm{S}$ $51^{\circ} 37^{\prime} \mathrm{W}$; MPEG 8757,1, $72.3 \mathrm{~mm} \mathrm{SL}$, rio Amazonas, $2^{\circ} 08^{\prime} \mathrm{S}$ $51^{\circ} 31$ 'W. MPEG 17451,1, $117.9 \mathrm{~mm}$ SL, rio Saracá, tributary of rio Trombetas. Tetranematichthys quadrifilis: MPEG 14668,1, 75.4 mm SL, igarapé Guaraná, rio Tapajós, 2²9'S 56¹3'W; MPEG 16198,2, 137.4- 108.52 mm SL. MPEG 10874 (1, $19.1 \mathrm{~mm} \mathrm{SL).}$ MPEG 6591,1, $119.8 \mathrm{~mm}$ SL, rio Amazonas, 09²8'S 531' 'W; MPEG 6535,1, $127.2 \mathrm{~mm}$ SL, igarapé Tijuquaquara, rio Amazonas, 143'S 51³0'W; MPEG 4373,2, 164.9- 173.1 mm SL, rio Amazonas Furos- Estuário; MPEG 8889,1, 148.7 mm SL, igarapé Curuá, rio Caxiuanã, $1^{\circ} 44^{\prime} \mathrm{S} 46^{\circ} 62^{\prime} \mathrm{W}$; MPEG 8119, 1, 70.4 mm SL, rio Urucu, tributary of rio Solimões, $4^{\circ} 51^{\prime} \mathrm{S} 65^{\circ} 40^{\prime} \mathrm{W}$; MPEG 8710,1, 78.2 $\mathrm{mm} \mathrm{SL}$, rio Amazonas, $1^{\circ} 46^{\prime} \mathrm{S} 51^{\circ} 37^{\prime} \mathrm{W}$.

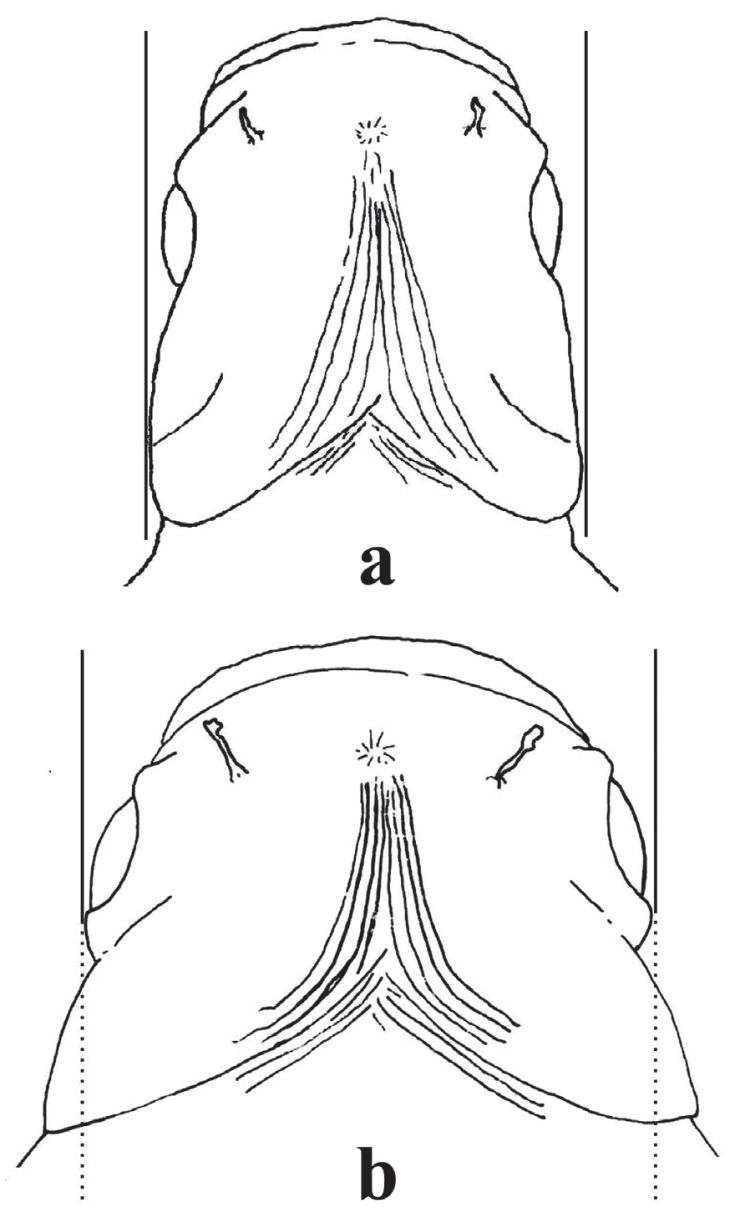

Fig. 5. Ventral view of head and anterior portion of (a) Tetranematichthys barthemi, holotype, male, MPEG 11081, $154.2 \mathrm{~mm} \mathrm{SL}$; and (b) Tetranematichthys quadrifilis, MPEG $6535,127.2 \mathrm{~mm} \mathrm{SL}$, showing the difference between the alignments of the postorbital portion of head.

\section{Acknowledgements}

The authors are grateful to T. O. B. Ruffeil for helping during the collection of this material. We thank Dr. L. R. PyDaniel (INPA) for loaning the paratype material. Field work was financed by STCP Engenharia de Projetos Ltda in agreement with the Mineradora Rio do Norte mining company as part of the Project 03MRN0407 - Preparation of EIA/RIMA Study Report and Environmental Impact of Bacaba Plateau. The senior author received a PIBIC scholarship (protocol 112068/2007-3). The material was collected under the license No 008/2007-CGFAP/IBAMA (Proc. 02001.003082/2007-44).

\section{Literature Cited}

Bleeker, P. 1858. De visschen van den Indischen Archipel. Beschreven en toegelicht. Siluri. Acta Societatis Regiae Scientiarum IndoNeêrlandicae, 4: 1-370.

Burgess, W. E. 1989. An Atlas of Freshwater and Marine Catfishes. A Preliminary Survey of the Siluriformes. Neptune City, T.F.H. Publications.

Ferraris, C. J., Jr. 2003. Auchenipteridae. Pp. 470-482. In: Reis, R. E., S. O. Kullander \& C. J. Ferraris, Jr. (Eds.). Check list of the freshwater fishes of South and Central America. Porto Alegre, Edipucrs, 729p.

Ferraris, C. J., Jr. 2007. Checklist of catfishes, recent and fossil (Osteichthyes: Siluriformes), and catalogue of siluriform primary types. Zootaxa, 1418: 1-628.

de Pinna, M. C. C. 1998. Phylogenetic relationships of neotropical Siluriformes (Teleostei: Ostariophysi): historical overview and synthesis of hypotheses. Pp. 279-330. In: Malabarba, L. R., R. E. Reis, R. P. Vari, Z. M. Lucena \& C. A. S. Lucena (Eds.). Phylogeny and Classification of Neotropical Fishes. Porto Alegre, Edipucrs, 603p.

Reis, R. E., S. O. Kullander \& C. J. Ferraris, Jr. (Eds). 2003. Checklist of the freshwater fishes of South and Central America. Porto Alegre, Edipucrs, 729p.

Vari, R. P. \& C. J. Ferraris, Jr. 2006. The catfishes genus Tetranematichthys. Copeia, 2006(2): 168-180.

Accepted December 18, 2009 Published March 31, 2010 